\title{
Formation and development of environment in Kyrgyz literature and journalism
}

\author{
Nurzhan Dzhumagazieva ${ }^{1, *}$ \\ ${ }^{1}$ Kyrgyz National University named after J. Balasagyn, Bishkek, Kyrgyzstan
}

\begin{abstract}
The purpose of the scientific article is to consider the stages of formation of the term "environment" in Kyrgyz literature and journalism. The article considers the specifics of journalistic literature of Kyrgyzstan as part of the general socio-cultural context of the country, and reviews journalism and socially oriented poetry of the Kyrgyz people. The place of the concept "environment" in the works of authors of Kyrgyzstan is determined. An analysis of the main periods of development of journalism in Kyrgyzstan was made, which allowed us to trace the etymology of the term "environment". The topic of the development of environmental issues in the works of Kyrgyzstan is relevant in the modern world, as the rapid development of industry and the increasing level of urbanization contributes to environmental degradation. Within the framework of a global scale, consideration of this problem in the framework of literary analysis will allow us to formulate the importance of the educational function of journalism in solving environmental issues. Environmental issues are popular. However, the topic of formation and development of the environment in Kyrgyz literature and journalism has not been studied. That is why the scientific novelty of the work is to develop a periodization of the evolution of ideas of environmentalism in literature and journalism. The methodological basis of the research is the analysis of literary and journalistic works of Kyrgyzstan at different stages of development of the territory under consideration.
\end{abstract}

\section{Introduction}

The deterioration of the environment in the XX-XI centuries is due to a high anthropogenic process: intensive development of industry, energy, transport, chemicalization of agriculture and urbanization.

According to academician Vernadskiy V., human becomes the greatest geologic force that changes our planet. A new advanced direction in biosphere research is geochemical ecology, the purpose of which is to study the regularity of interaction between individual organisms and their associations based on their migration and transformation of chemical element in the biosphere.

\footnotetext{
*Corresponding author: nnn330@yandex.ru
} 
Environmental compatibility should be considered in the context of human security, which includes various categories: economic stability, food safety, health security, environmental compatibility, personal safety, public and political security.

Tough economic situation observed in the last century of the outgoing millennium everywhere in the world and, in particular, in the Kyrgyz Republic, leading to deterioration in the living conditions of people and the entire biodiversity - this is a real threat to humanity in the third millennium. Kyrgyzstan is a mountainous country that is particularly vulnerable to natural and anthropogenic impacts and is going through a difficult period of transition to a market economy. It is important to take into account environmental factors in the policy of economic reforms along with social aspects. The issue of the future of the country and humanity as a whole is on the agenda. Ecology is not only care of the environment, it includes correlation study not only between biosphere components and local ecosystems but also the relationships between people and the organization of society as a whole. So, ecology will be the leading science of III millennium.

Reliable, objective and timely assessment of the environmental condition is necessary for the prevention and elimination of negative anthropogenic impact on the environment and creating a normal human environment. Only in this case it is possible informed decision making on regulating the quality of the natural environment.

For example, in the republic the sanitary water quality control is almost completely violated. Discharge of wastes weren't processed due to the lack of technical equipment. Therefore, the incidence of the gastrointestinal tract diseases has increased over the last years.

Food quality control has significantly deteriorated and, as a result, the number of cases of hypovitaminosis, gastrointestinal diseases and others has increased.

Thus, the level of public health care is related to the negative environmental conditions of the republic and requires urgent measures in the field of environmental hygiene.

Thus, the level of public health is connected with the unfavorable environmental situation in the Republic and requires measures in the field of environmental hygiene.

Modern mass media plays an important role in dissemination of environmental knowledge among population. Journalism takes a leading position in the formation of ecological world outlook for high readership. Every year, the cultural and educational function of journalism becomes more and more important, because our world becomes to realize the importance and complexity of environmental issues. Often, ecologists and environmental organizations underestimate mass media as a powerful source of power that can solve a lot in the field of environmental protection.

The problem of the research is an insufficient development of environment topic in Kyrgyz literature and journalism, as well as insufficient attention to environmental issues, and sometimes mistakes and inaccuracies in providing information about the environment.

Currently, the environmentalist theory, which involves strengthening measures to protect the environment, as well as managing socio-economic development and the environment, is widely publicized. This theory is widely spread in European countries from $\mathrm{XX}$ century. The main concept is environment.

Environmental issues are quite popular. Today, the synergistic effect on the environment is considered in the works of Nikolskaya Yu.V. and Subbotina Yu.M. (2015) [1]. The topic of environmental crimes is widely publicized in the works of Builov O. P. and Brusentsev V. I. (2015), Medvedeva A. A. (2015) [2,3].

The environmentalist theory is quite popular due to the ecological and educational activities considered in the works of Tauchelov Z. V. and Agaeva F. A. [4]. The environmental situation in Kyrgyzstan is discussed in the article of Zhanakeeva A. T. [5]. The author uses concrete examples to highlight the main environmental issues and ways to 
solve them. The influence of ecology on the quality of life of the population in Kyrgyzstan is considered in the article of Sadyraliev $\mathrm{Zh}$. [6].

The main tendencies in the development of the country, associated with environmental degradation, its impact on the environment and quality of life of the population of this territory were identified, one aspect of which is environmental factor.

Environmental issues are very popular. However, the topic of formation and development of environment in Kyrgyz literature and journalism has not been studied. That is why the scientific novelty of the work is to develop a periodization of the ideas evolution of environmentalism in literature and journalism.

The practical significance of the study is to systematize information about the first mentions of the term "environment" in Kyrgyz literature and journalism.

\section{Main text of the scientific work}

Considering the stages of formation of Kyrgyz national (printed) literature and journalism, the genesis of this process should be attributed to the beginning of the XX century. At that time, conditions for the formation of book publishing and periodical publications were the lack of material resources and extremely low literacy of the general population of the Kyrgyzstan. Literacy was mainly instilled in the Muslim religious education, where Arabic language was taught to read the Koran and other texts. Therefore, the main people of this cohort of national intellectuals were Moldo - people who received a classical Muslim education, who could read and write in Arabic language. At that time, literature was more religious than scientific nature.

\section{Development of environmental issues at the beginning of the XX century}

The most popular form of journalistic work is gradually becoming an essay, while taking into account its different thematic scope; it can be divided internally into types, where the industrial essay is put forward in the foreground in the journalism of that time. One of the most consistent adherents of this genre type was the famous soviet journalist and writer Boris Gorbatov. He actually shaped it as such, putting at the forefront the working man, the thirst of which he is overwhelmed. The most famous works of Gorbatov B. are essays "Cast Iron", "Risk", "Comintern" and "Comb". In turn, "Ordinary Arctic" is the book of essays written in the 30s, which devoted to the development of the Far North.

Considering them in more detail, it should be noted that no matter how much the author is passionate about the characters and their achievements, he describes the nature almost in every essay. However, the description of nature for Gorbatov B. wasn't the goal in and of himself, but an important display mean of that conditions, in which certain events occur, for the most clear formation of the reader's idea and, moreover, a sense of the reality of what is described, that the reader himself, along with the characters and the author of the essay, participates in certain events.

Here is how one of the most famous essays of Gorbatov B. "Cast Iron" begins: "A frosty January morning crackled over the blast furnace. The snow was sharp and brittle. The laborer stopped and took a deep breath. There was frozen white steppe below him - a light wind blowing through it, curling the snow dust. Bashkir was born here, in the district; his father drove shoals of horses across the desert steppe. Other people's shoals, nothing was beaten; only a lot of children had a lot of troubles. There are no shoals here now locomotives run on the mountain. This Bashkir sees well from the height of the blast furnace. ... The worker forgot why he was sent, — stared. Under the morning sun, mount 
Atach glows crimson - three hundred million tons of ore, not yet melted into cast iron, cold, dead...". From the above excerpt clearly shows that the reflection of nature in addition to landscape and mental functions forming the reader a clear idea of the place and explanation of climatic circumstances, he intended also to show the contrast between old and new life, to focus, more highlight the changes that happened to the lifestyle and whole society of the Bashkir steppe. The description of nature used here was for the formation of the reader's most complete mental picture.

Another important area of Soviet journalism at the beginning of the second third of the $\mathrm{XX}$ century was the agricultural essay, which at that time was seriously advanced. The most intensive participation in its development belongs to such well-known Soviet journalists as Stavskiy Vl. and Kolosov A. The geographical point of attraction for Vladimir Stavskiy (Kirpichnikov) was the southern regions of the USSR, specifically the Kuban. He described the landscapes of the Kuban most intensely and used them for introduction the reader with the atmosphere and circumstances of what is happening with the characters of the essay. Here is how the nature of Taman is described in the essay "Stronger than death": "Just behind the houses of the station - a multi-planted clay cliff. The surf booms on the beach below. Far away - along the Kerch Strait - the swift Levant (wind) drives terribly cold waves from the South green in echoing crests. Beyond the Strait, Crimea floats in a blue haze. The great bluffs at the ends of the Strait stand out sullenly. Near the water there are pink and white spots of Kerch, villages between them, in the undulating folds of the mountains. You can see here the smokestacks of the Bryansk metallurgical plant" [7]. At the beginning of the XX century, the topic of environmental issues in Kyrgyz literature and journalism is shown in essays. The essays reflect the concept of "environment" and equate it with the meaning of "nature".

\section{The concept of "environment" in the pre-war and war periods}

Nature essays were actively developed in the pre-war and post-war periods. This statement is fully applicable to all Soviet print journalism, which was most actively developed at this time. At that time, the most active journalistic works were published by the most prominent Russian-Soviet writers, such as Aleksey Tolstoi, Nikolai Tikhonov, Ilia Erenburg, Mikhail Sholokhov, Konstantin Simonov, Boris Gorbatov, Leonid Sobolev, Vsevolod Vishnevskiy, Leonid Leonov, Marietta Shaginyan, Aleksey Surkov, Vladimir Velichko and others. Their works carried a huge charge of patriotism, faith in victory over a terrible enemy, and helped educate the masses in the spirit of love and devotion to their homeland.

The most famous Russian-Soviet writer Aleksey Tolstoy became actively involved in publicistic activity. On June 27, 1941, his first military article "What we protect" appeared in the Pravda newspaper. In this newspaper, the author addresses the essence of the soul of the Russian people, the archetypes of his worldview, the innermost components of consciousness, and much more. Describing the essence of Russian life, he writes the following lines: "I remember the dead silence ..., a poor village with omets, thatched roofs and branches on the bank of a steppe river.

I look into the past, and I remember smart, clean, unhurried people who protect their dignity. For example, the father of my playmate - Alexander Sizov, a handsome man with a curly brown beard was a strong man. When the village began the battle in the snow - the end was the end, - Sizov looked at the window with merry eyes, went out and stood at the gate, and when he was asked to help them, he dressed golitsy and jokingly poured the entire wall; in thin short fur coat, wound a scarf round neck, he walled a hundred miles in the snowstorm for a cartload of wheat; he carried all his meagre annual income to the city. 
Today, his grandson is probably throwing himself like an angry Falcon at German bombers."

Summing up, in order to answer the question displayed as the title of the article - "What do we protect?!» the author draws a brief but full descriptive picture of the life of the Soviet Union, which, in his opinion, should have been defended by all the people: "From ocean to ocean, collective farm fields rustled with gold, gardens bloomed and cotton was puffed up where only recently dead sand was blowing. Tens of thousands of factories were filled with smoke. The same grandson of Alexander Sizov, the same hero, went to turn, like a Titan, one hundred tons of coal per shift. Thousand - ton hammers, shaking the earth, began to forge weapons of the red Army - the army of the liberated people, the army of freedom, the army-the defender of peace, higher culture, prosperity and happiness on earth"[8].

Kyrgyz literature and journalism also actively responded to the General Patriotic impulse to protect the Motherland from the insidious and cruel enemy. Among the large number of materials written in this direction, special attention is drawn to publications about the help and support of the people of Kyrgyzstan for the heroic defenders of Moscow and Leningrad in October - November 1941 and up to 1943.

For example, "Kyzyl Kyrgyzstan" and "Soviet Kyrgyzstan" newspapers published reports, sketches and essays about repeated deliveries of food to Leningrad, organized by Kyrgyz leaders and delegations, about sending special echelons, on behalf of the population of Kyrgyzstan, with material assistance and concert teams to the soldiers who defended Moscow. One of the October numbers of "Kyzyl Kyrgyzstan" newspaper published in 1941 was almost entirely devoted to the defense of Moscow.

Patriotism was a characteristic feature of the ecological theory of that time. Here, the term "environment" still remains at the level of the natural component. However, in the works and publications there is a reverence for nature. This is a new stage in the development of environmentalist theory in the Kyrgyz SSR.

\section{5 «Environment» in post-war periods}

The Great Patriotic War, which ended victoriously on May 9, 1945, put the Soviet Union in front of the need to solve a huge mass of problems. The first of them was the need to reorient the masses from conducting combat or military labor activities to restore the country destroyed by the war. As a result of fighting, shelling and bombing, more than 70 thousand settlements - cities, towns and villages - were destroyed. Stalingrad, Sevastopol, Kiev, Minsk, Odessa, Smolensk, Orel, Kharkiv, Rostov-on-Don and many other cities were in ruins. Restoration required about 32 thousand industrial enterprises, 65 thousand kilometers of railways and more than 4 thousand railway stations. Tens of thousands of schools, hospitals and libraries were reduced to ashes [9]. Under these conditions, the Soviet press had to be transferred to peaceful tracks, which, as during the war, had to conduct propaganda, explanatory work, restore, and form anew the peacetime mentality of the country's population.

Soviet journalism at the Union level played an important role in this issue. That time, A. I. Kolosov, I. A. Ryabov, B. N. Polevoi, V. V. Ovechkin, B. A. Galin, V. V. Poltoratskiy, A.V. Kalinin, V. F. Tendryakov, G. N. Troepolskiy, T. N. Tess, M. S. Shaginyan and many other published their works on the pages of newspapers. An important role in the development of Soviet journalism in the period under review was played the works of the famous Soviet writer, Nobel Prize winner Mikhail Sholokhov, whose articles, essays, pamphlets and notes were published in "Pravda", "Izvestia", "Literaturnaya Gazeta', 'Komsomolskaya Pravda', as well as local newspapers. So, "Pravda" newspaper published his essays "Word of the Motherland", "Beloved mother-fatherland", "Firstborn of great construction projects", pamphlets "Light and darkness", "Do not escape the executioners 
from the court of Nations!", articles "Victory, which history did not know" and many other materials [10].

The key work for Sholokhov's work as a publicist at that time was the essay "The word about the Motherland", written in 1948. Opening it, the writer addresses his reader not as a combat or labor colleague, but as a compatriot and a good friend.

Opening the essay, he also, with his inherent talent and accuracy of reflection, describes the nature of his native country - what soldiers fought and died for on the war fields: "Winter. Night... Stay a little in silence and solitude, my dear countryman and friend, close your eyes, remember the recent past, and in your mind's eye you will see: ...A cold, whitish fog swirls ghostly over the forests and swamps of Belarus, over empty, long-abandoned dugouts overgrown with withered ferns, over collapsed trenches and rusted - water rifle cells. Rifle cartridge case, green with age, and gleam dully at the bottom... Under the thick North wind, the peaks bend and the pine trees of the Smolensk region and the Moscow region cut by splinters make a dull noise. Snowing, as it is in a hurry to cover the war-torn, sacred land for our people in the vicinity of the immortal city of Lenin. Sunny shadows glide across the resurrected fields of Ukraine, plowed many times by shells, still remembering the thunderous rumble of unprecedented battles. Near Kursk and Orel, near Voronezh and Tula, a slanting snowstorm is spreading over the primordial Russian land, which for three years has groaned under the weight of tens of thousands of tanks; the last frost - burned leaves are falling from the trees, and everywhere-in the fields, on highways and byways, along and across, step by step trodden by the patient feet of our best infantry in the world - they turn red like blood ...And in the Crimea, in the blue foothills of the Caucasus, dazzling white threads of the web still float in the clear, cold air. In fine morning dawns, where once the fighting did not cease, ospreys and funnels, fringed with shaggy weeds, like a silver net, are covered with cobwebs, and every thread of it bends and trembles quietly, all covered with tiny sparkling tears of dew..."[11].

At that time, the idea of environment transformation for the benefit of man and for the development of society and the state was one of the central ideas in many artistic and publicistic works. Here, the dissertation traces a certain duality, which will later be clearly highlighted by environmental journalism.

However, publicistic works devoted to the nature of the Kyrgyz land were also published in Moscow at the Union level. So, in 1950, the work of a descriptive and geographical nature "Frunze - the capital of the Kyrgyz SSR" was published, the author of which was S. N. Ryazantsev. Here is a description of Frunze city location and its nature: "the city of Frunze lies almost in the center of the Chui valley, on a foothill plain, near the foot of the side ridges of the Kyrgyz Ala-Tau, the snow-capped peaks of the ridge rise to the South of the city as a majestic amphitheater. An open steppe plain extends in all other directions. On it, among the fields, you can see numerous settlements - either old villages hidden by the greenery of powerful pyramidal poplars and gardens, or new settled Kyrgyz kyshtaks, which have already grown young tree greenery. This cultural plain stretches far to the North, where the gray contours of the low Chu-Ili Mountains are outlined in clear weather. In summer, the panorama of Frunze from a distance is a solid mass of green: poplars, oaks, elms, fruit plantations; above its General carpet, you can see only the roofs of houses and the upper parts of taller buildings and factory chimneys protrude. Green hides the rectangular layout of the city with its very similar streets and small blocks...".

Analyzing the above passage and the book as a whole, it should be noted that they continue the general trend of Soviet journalism of that time - combining landscape (geoclimatic, landscape) sketches with ideological conclusions about the leading and guiding role of the Soviet government in the positive transformations taking place in the most remote corners of the country. 


\section{Critical time in the $60 \mathrm{~s}-80 \mathrm{~s}$ of the XX century}

Considering the development of Kyrgyz journalism and publicism during this period, it should be noted that the trend of its evolution with the general development of Soviet journalism continued to persist. So, in the $60 \mathrm{~s}$, we can note an increased level of independence of national journalism, which, however, became appropriate for all Union journalism at that time. This increased level of the artistic freedom and expression of one's civic position was due to the general direction of the political development of the Soviet Union, which in history was called the "thaw" period. Under these conditions, many journalists and publicists resolutely and openly covered various problems and issues of the development of the national economy, politics, culture and social life of the Republic.

The content of national mass media releases changed a lot at that time. On the pages of newspapers and magazines, the authors of articles and essays revealed interesting and problematic materials that touched on the urgent tasks, aspirations and needs of Kyrgyz people. It was in the sixties that the most active creative period began as a publicist of the Nobel Prize winner, writer Chingiz Aitmatov, whose articles and essays were published in newspapers and magazines, broadcast on radio and television. As resident correspondent of "Pravda" newspaper for Kyrgyzstan and the Central Asian Republics, he published essays and journalistic articles about the life of these republics, published in various Union and Republican publications. I remember his essays "Golden gate", "Winds washing the earth", "Snow on Manas-Ata"[12].

The next two decades are connected with such a phenomenon as "stagnation" in the complex development of the USSR, which occurred during the reign of L. I. Brezhnev (1964-1982). At this time, but not immediately, in the early 70s, a solemn and laudatory tone began to prevail in mass media, and the problems of social and economic development that journalists sought to identify were characterized as isolated phenomena not peculiar to the country or the Republic as a whole. At the beginning of the 80 's, it became obvious that the USSR, and the Union republics, are more and more deeply immersed in the economic, social and political crisis, caused, by the fact that the principles of command and administrative management no longer meet the requirements of modern times. However, in newspapers, magazines, on radio and television, sublimely ceremonious correspondence about the smelted, extracted and threshed prevailed during the reporting period, while, at the management level, problematic issues and threatening facts of reality were either hushed up or openly denied. Therefore, we have to state the absence of acutely problematic materials, such as: essays by V. Peskov, books by V. Agranovskiys, and articles by $\mathrm{Ch}$. Aitmatov at that time in the Republican and Union mass media.

Nevertheless, it should be noted that even in such conditions, the national mass media continued to develop mainly in quantitative and material-technical relations over the period under review. Thus, in the mid-1980s, there were 111 newspapers published in Kyrgyzstan with a one-time circulation of 1353 thousand copies, including 61 newspapers in the Kyrgyz language with a one-time circulation of 792 thousand copies and 44 magazines and other periodicals with an annual circulation of 34665 thousand copies. Kyrgyz book publishing was rapidly developing. In 1964, the Kyrgyz state publishing house was transformed into "Kyrgyzstan" publishing house. "Kyrgyzstan", "Mektep" and "Ilim" publishing houses published educational and mass-political literature, scientific works, and works of art. In 1985, 1112 titles of books and pamphlets were published with a total circulation of 8223 thousand copies, compared to 843 titles with a circulation of 4981 thousand copies in 1960. In 1988, on the basis of "Kyrgyzstan" publishing house, "Adabiyat" ("Literature") publishing house was created for publishing books of fiction. In turn, "Kyrgyzstan" publishing house specializes in publishing mainly mass-political books [13]. 
In the early 80's, the talent of the writer and journalist Cholponbai Nusupov was widely developed. In his works, stories and essays, combined in "Steep passes" book published in 1981, he continues the traditional trend for Kyrgyz literature of a heartfelt and poetic reflection of the nature of his native land.

Analyzing the state of the Union journalism of that period, it should be noted that in it, in relation to the topic of this study, two main trends can be distinguished. First, sociopolitical, which is a prominent representative of A. Agranovskiy, and secondly, geographical and landscape, represented by the famous Soviet writer, journalist and TV presenter V. Peskov. The first one relied on exposing the problems of contemporary Soviet society, their detailed analysis in relation not to point out the remnants of the past, but to analyze the behavior of specific individuals, their actions and inaction. Therefore, for him, nature and its display is only a background and addition to the analysis of human passions and actions generated by them.

Summarizing the review, it should be noted that during the period of the $60 \mathrm{~s}-80 \mathrm{~s}$, two leading trends were formed in the development of publicistic reflection of the environment in the Kyrgyz national literature and journalism: the first is geographical and economic, where descriptions of nature are sparse and schematic. Similar to those used in essays of B. Polevoi and the second - artistic and aesthetic, subsections of which are aesthetic and moral and landscape reflection. An adherent of the first were, of course, Ch. Aitmatov, prominent representatives of the second one can be called Sh. Beishenaliev, Ch. Nusupov and M. Baidzhiev, but also in their works, the reflection of nature is organically intertwined in the binding of the narrative and does not act as an end in itself.

\section{Period of Perestroika in the "environment" of Kyrgyzstan}

Considering the issue included in the title of this paragraph, it should be noted that the Kyrgyz national journalism during the period of perestroika - 1985-1991 continued to develop with the development of all-Union literature and journalism. At that time, due to the tragic events that occurred in several places on the territory of the USSR, which were associated with man-made disasters, there was a full-scale turn in the Union journalism towards the environmental issues of the development of civilization, the cost of human control of nature, and the results of a thoughtless attitude to the possibilities of technological progress.

Among the largest accidents and tragic catastrophes were the explosion at the Chernobyl nuclear power plant (April 30, 1986), emissions at the Nefteorgsintez plant in the city of Kirishi (mid-80's), the fall in the level of the Aral sea, the crazy project of turning the Siberian rivers and others. Union journalism responded dynamically to these challenges. Let's look at the works published at that time in more detail.

1. Zalygin

2. Chernobyl

3. Aral, Kirishi

One of the most prominent publicists of the Union level of the period of perestroika, who worked in environmental issues, was Sergei Zalygin. Perceiving nature as a perfect and dynamic system, he saw its elements in relationship and balance, in turn, in his opinion, is a compromise of the living and the non-living, where the key quality of the system of being is a reasonable beginning. Based on this, a person is included in it organically, being an integral part of the natural integrity, being a genetically natural being. At the same time, in his opinion, the nature being the highest rational organization, that acts as the source of human reason.

In these conditions, a large place in his thoughts is occupied by the question of human interaction with nature and its results. Analyzing such results, the publicist states that the 
result of human development, his freedom, even barbaric, attitude to nature is a violation of the balance of being as a whole.Under these conditions, he writes: "The natural process ... is not part of our daily life, we ... feel a Rubicon between this process and ourselves." This situation, in his opinion, creates a separation from nature and leads to the inferiority of man as a natural being, the loss of the pillars of existence: "...we are also part of nature, and by conquering the whole, we inevitably disfigure the part of it that is ourselves"[14].

Most fully, its ecological pathos resulted in the fight against the project of turning the Siberian Rivers, which is disastrous for the global ecosystem, including through the use of underground nuclear explosions. The publicist's struggle against this disastrous project is dedicated to the collection of works "Turn" published in 1987 [15]. Becoming a key collection of environmental and journalistic topics of S. Zalygis, it includes program works published after the April Plenum of the CPSU Central Committee in 1985, when the party set a course for perestroika.

On these pages S. Zalygin reveals his perception and representation of nature, reflecting on the project "turn". In particular, he considers the disastrous consequences for the environment of departmental projects of mindless transformation of nature - the construction of a dam in the Kara-Bogaz Bay, which separated it from the Caspian Sea, salinization of soils during irrigation from Sasyk Lake, and the tragedy of the Karakalpak lands. There are also warnings about poorly developed projects of questionable expediency, such as diversion of the Danube water to the Dnieper, ensuring full regulation of the Yenisei flow by a cascade of 12 dams, the Daugavpils hydroelectric power station, the barrier dam in Leningrad, and the Rzhev reservoir. At the same time, the articles presented by the author in the collection are broader than just philosophical essays. They contain serious arguments of the author's position, supported by reports from the Central press and clippings from local newspapers. In turn, regarding the irrigation, being a hydroengineer by profession, S. Zalygin actively uses his own observations. In particular, he identified low agriculture under irrigation, which leads to the loss of thousands of hectares of productive land per year - the death of arable land, pastures, degradation of chernozem, waterlogging of the desert, reduction of fresh water resources, etc. He also noted that activities to change the hydrogeographic landscape also lead to climate change.

At the same time, thought and analysis of the situation leads S. Zalygin to a new understanding of the role and capabilities of society in the renewing state, in which "perestroika" is taking place. Active discussion about the project is interpreted by him as a reflection of objective processes of transformation of public consciousness - the emergence of civil independence in new political conditions, which led to the closure of the project.

Significant activation of the Union environmental journalism occurred due to the tragic events at the Chernobyl nuclear power plant on April 26-27, 1986. According to the wellknown psychologist A. Kharash, a line was developed to "calm" the population by influencing it through mass media [16]. So, on May 10, 1986, "Pravda" newspaper published an article by V. Gubarev and M. Odinets "From Chernobyl to Kiev" [17]. This is not a large correspondence, the main emphasis is on what works on liquidation of consequences of the disaster being deliberately and courageously, all measures are taken, the relocation of people from contaminated areas, every effort is made to prevent any emergency and, in particular, the spread of radioactive contamination. At that time, a huge mass of articles were published in both the Central and Republican periodical press [18].

Summarizing, it should be noted that in the Kyrgyz national journalism of the perestroika era there was a kind of intellectual turn, where instead of geographical and landscape or technological and economic aspects of reflecting the surrounding nature, publicists turned to the most important issue - human nature, its behavior and, more generally, activity. It is traditional for Kyrgyz national literature, the basis of which we saw even higher, in the pre-written forms of Kyrgyz oral epic creativity, represented primarily 
by the global epic "Manas", to measure everything in the prism of a person, his actions and deeds, the moral measure that he has defined for himself, from the standpoint of which he will be evaluated.

\section{Kyrgyz journalism of the period of independence about the environment}

The beginning of the period of independence of Kyrgyzstan can be dated on August 31, 1991, when, in the wave of political events related to the proclamation and overthrow of the power of the State Committee on the State of Emergency, the Supreme Council of the Republic of Kirghizia declared independence of the Republic. This is considered the starting point for the formation of an independent national press and journalism in Kyrgyzstan. Periodization of its development was proposed in work "History of development and current state of mass media in Kyrgyzstan" made by G. Ibraev and S. Kulikov. In their opinion, the entire period of development of the independent national press and journalism in Kyrgyzstan can be divided into 5 main stages:

1. 1991-1992 - proclamation of press freedom;

2. 1993-1995 - distancing from the state authorities, developing your own positions on the role and functions of mass media;

3. 1996-1999 - the final "separation" from the government.

4. 1999-2005 - distribution and concentration of media ownership, through the formation of media holdings;

5. Since 2005 to the present days - the redistribution of media ownership and the strengthening of the influence of media holdings, by combining them and concentrating them in one center or "one hand" [19].

Describing them, it should be noted that, in most cases, the central topics of Kyrgyz national journalism during independence are political issues of national self-determination and development of national consciousness of the Kyrgyz people, building a democratic, developed Kyrgyzstan, implementing honest and correct policies, preventing distortions and abuses, and generally determining the main path of development of society and the state.

Meanwhile, it should be noted that the tendencies of publicistic reflection of the environment laid down at the previous stage of development of the Kyrgyz national literature and journalism were actively manifested and received their intensive development. There are three stages:

1. Geo-ecological;

2. Environmentalist (landscape and portrait);

3. Mixed.

Summing up the review, it should be noted that the Kyrgyz journalism of the period of independence, dedicated to the reflection of the environment, is very rich, has a variety of reflection complexes and is reduced to the three groups mentioned above. Meaningfully, the Kyrgyz journalism of this period in relation to the display of nature continued to preserve the traditions laid down earlier, where nature is displayed not only as a phenomenon of the surrounding reality, but as a measure of human morality, an occasion for him to understand his place and purpose in this world. 


\section{Discussion}

The development of Kyrgyz national journalism in the late 20s and early 40s of the XX century was influenced by a number of external and internal socio-political, cultural and demographic factors. It is possible to say that at that time the first factor of journalism and literature evolution in the Union republics was along with all - Union journalism, represented by trends and publications in the central press - newspapers and magazines of the all-Union level. One of the most global processes that caused a radical socio-cultural revolution in the Kyrgyz society of that time was the mass transfer of the Kyrgyz to settlement. It meant almost complete reconstruction of the culture, everyday life and economic structure of a significant part of society and, as a result, the transition to a higher civilizational level.

Under these conditions, the authors of journalistic works used the reflection of the environment to create the most accurate and complete picture of what is happening for the reader, to introduce him to a special mental and psychoemotional state for the most clear and correct feeling and understanding of what is happening on the pages of the work, what he wants to show.

During the difficult time of the Great Patriotic War, Kyrgyz literature and journalism also actively responded to the general patriotic impulse to protect the motherland from the insidious and cruel enemy.

At this time, publicists actively used techniques and means of reflecting the environment, linking their aspirations with it, because it is the expression of their native land, which Kyrgyz baatyrs went to protect as they did it since ancient times, under the leadership of the great Manas.

The Great Patriotic War, which ended victoriously on May 09, 1945, put the Soviet Union in front of the need to solve a huge mass of problems. The first of them was the need to reorient the masses from conducting combat or military labor activities to restore the country destroyed by the war.

Regarding the Kyrgyz national journalism of the post-war years, it should be noted that in the first post-war decade, Kyrgyz society, on the one hand, developed with the entire Soviet society and, at the same time, had a number of significant features. The key ones were that the territory of the Kirghiz SSR was not affected by the fighting and, therefore, the problem of restoring the destroyed was not as acute as in other parts of the USSR, which was the war.

In the display of nature by Kyrgyz publicists of that period, there was a tendency to combine geographical and landscape sketches with ideological techniques to identify new trends in the development of the area and changes in the landscape

Considering the development of Kyrgyz journalism and publicism during this period, it should be noted that the trend of its evolution in line with the general development of Soviet journalism continued to persist.

During the period of the $60 \mathrm{~s}-80 \mathrm{~s}$, two leading trends were formed in the development of publicistic reflection of the environment in the Kyrgyz national literature and journalism: the first is geographical and economic, where descriptions of nature are sparse and schematic.

During the period of perestroika (1985-1991), Kyrgyz national journalism continued to develop in line with the development of all - Union literature and journalism. At that time, due to the tragic events that occurred in several places on the territory of the USSR, which were connected with man-made disasters, there was a full-scale turn in the Union journalism towards the environmental issues of the development of civilization, the cost of human control of nature, the results of a thoughtless attitude to the possibilities of technological progress. 
In the development of journalistic reflection of the environment, Kyrgyz literature during the period of perestroika, there was an intellectual turn, where instead of geographical and landscape or technological and economic aspects of reflecting the environment, publicists turned to the most important issue - human nature, its behavior and, more generally, activities.

The beginning of the period of Kyrgyzstan independence can be dated on August 31, 1991, when, in the wave of political events related to the proclamation and overthrow of the power of the State Committee on the State of Emergency, the Supreme Council of the Republic of Kyrgyzstan declared independence of the Republic. This is considered the starting point for the formation of an independent national press and journalism in Kyrgyzstan. Giving this period a comprehensive description, it should be noted that, in most cases, the central topic of Kyrgyz national journalism during independence are political issues of national self-determination and development of national consciousness of the Kyrgyz people, building a democratic, developed Kyrgyzstan, implementing honest and correct policies, preventing distortions and abuses, and generally determining the main path of development of society and the state.

Today there are a wide variety of subjects, forms and means of expression, which the candidate for a degree, in working order, called the reflection complex. One of the most common complexes of reflection is geolandscape. There are landscape descriptions of Kyrgyzstan landscape in the displaying of environment. The second most important complex is the reflection of the natural world of Kyrgyzstan.

Summing up the review, it should be noted that the Kyrgyz journalism of the period of independence, dedicated to the reflection of the environment, is very rich, has a variety of reflection complexes and is reduced to the three groups mentioned above. Meaningfully, the Kyrgyz journalism of this period in relation to the display of nature continued to preserve the traditions laid down earlier, where nature is displayed not as a phenomenon of the surrounding reality, but as a measure of human morality, an occasion to understand his place and purpose in this world.

\section{Conclusion}

Further study of the periods of development of ecology problem in the works and publications of Kyrgyzstan will allow us to trace the development of environmental education and the etymology of the term "environment". The analysis of works devoted to the nature and the environment allows us to consider the gradual change in the relationship between man and nature in the context of a regional problem in more detail. Through indepth study of environmental issues at one country level we can find a way to develop and improve environmental knowledge, which will reduce the environmental load within considered territory.

\section{References}

1. Yu.V. Nikolskaya, Yu.M. Subbotina, International student scientific bulletin 3-1 (2015) http://eduherald.ru/ru/article/view?id=12032

2. O.P. Builov, V.I. Brusentsev, International student scientific bulletin 2-3 (2015) http://eduherald.ru/ru/article/view?id=12264

3. A.A. Medvedeva, International student scientific bulletin $\mathbf{2 - 3}$ (2015) http://eduherald.ru/ru/article/view?id=12268

4. Z.V. Tauchelova, F.A. Agaeva, International student scientific bulletin 3-3 (2016) http://eduherald.ru/ru/article/view?id=15118 
5. A.T. Zhanakeeva, To the question of environmental security of Kyrgyzstan// The Newman in Foreign policy 52(96) (2020) https://cyberleninka.ru/article/n/k-voprosuobespecheniya-ekologicheskoy-bezopasnosti-kyrgyzstana/viewer

6. Zh. Sadyraliev, Bulletin of the Perm National Research Polytechnic University. Socioeconomic Sciences 4 (2018) https://cyberleninka.ru/article/n/vliyanie-ekologicheskoyobstanovki-okruzhayuschey-sredy-na-uroven-i-kachestvo-zhizni-naseleniya-vkyrgyzstane/viewer

7. M.P. Stavskiy, Stronger than death (OGIZ-Molodaya Gvardiya, M., 1933)

8. A. Tolstoi, What we protect. Pravda (1941)

9. The Great Patriotic War of the Soviet Union 1941-1945: A brief history (Voenizdat, M., 1984)

10. M.A. Sholokhov, Collected works in eight volumes. Volume 8 (Pravda, Moscow, 1962)

11. Ch.T. Aitmatov, Articles, speeches, dialogues, interviews (News press Agency Publishing house, M., 1988)

12. Kyrgyz Soviet Encyclopedias (1978)

13. S.P. Zalygin, Turn (Mysl, M., 1987)

14. V. Gubarev, M. Odinets, Pravda 130, 24752 (1986)

15. A. Illesh, Izvestiya 134, 21576 (1986)

16. A. Lobanov, Komsomolskaya Pravda 111, 18614 (1986)

17. M. Miroshnichenko, Ukraine Pravda 109, 13379 (1986)

18. Yu. Shcherbak, Youth 6-7, 9-10 (1988)

19. G. Ibraeva, S. Kulikova, History of development and current state of mass media in Kyrgyzstan (Bishkek, 2002) 